Keywords: Saltstone

TCLP

Retention: Permanent

\title{
Saltstone 3QCY10 TCLP Results
}

M.M. Reigel

December 2010

Savannah River National Laboratory Savannah River Nuclear Solutions Aiken, SC 29808

Prepared for the U.S. Department of Energy under contract number DE-AC09-08SR22470.

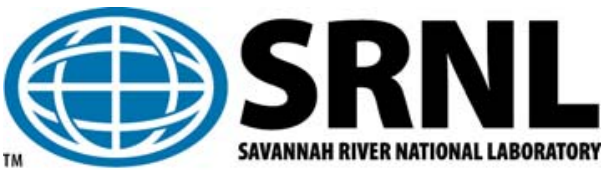


SRNL-STI-2010-00679

Revision 0

\section{DISCLAIMER}

This work was prepared under an agreement with and funded by the U.S. Government. Neither the U.S. Government or its employees, nor any of its contractors, subcontractors or their employees, makes any express or implied:

1. warranty or assumes any legal liability for the accuracy, completeness, or for the use or results of such use of any information, product, or process disclosed; or

2. representation that such use or results of such use would not infringe privately owned rights; or

3. endorsement or recommendation of any specifically identified commercial product, process, or service.

Any views and opinions of authors expressed in this work do not necessarily state or reflect those of the United States Government, or its contractors, or subcontractors.

\section{Printed in the United States of America \\ Prepared for \\ U.S. Department of Energy}




\section{REVIEWS AND APPROVALS}

AUTHORS:

M.M. Reigel, Engineering Process Development

Date

TECHNICAL REVIEW:

R.E. Eibling, Engineering Process Development

Date

APPROVAL:

A.B. Barnes, Manager

Date

Engineering Process Development

S.L. Marra, Manager

Date

Environmental \& Chemical Process Technology Research Programs

J.E. Occhipinti, Manager

Date

Waste Solidification Engineering 


\section{EXECUTIVE SUMMARY}

A Saltstone waste form was prepared in the Savannah River National Laboratory (SRNL) from a Tank 50H sample and Z-Area premix material for the third quarter of calendar year 2010 (3QCY10). After the prescribed 28 day cure, samples of the saltstone were collected, and the waste form was shown to meet the South Carolina Hazardous Waste Management Regulations (SCHWMR) R.61-79.261.24 and R.61-79.268.48(a) requirements for a nonhazardous waste form with respect to RCRA metals and underlying hazardous constituents. These analyses met all quality assurance specifications of USEPA SW-846. 


\section{TABLE OF CONTENTS}

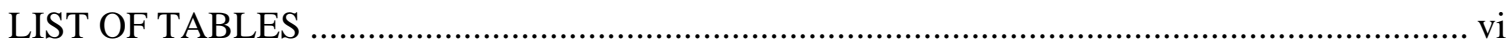

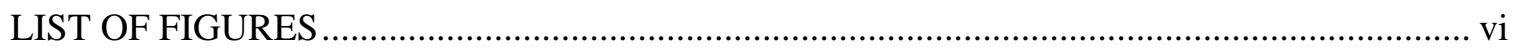

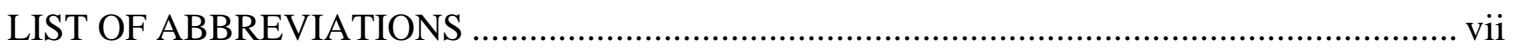

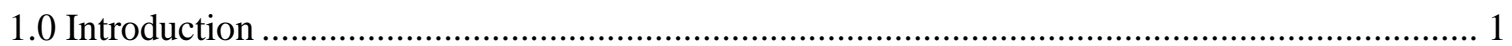

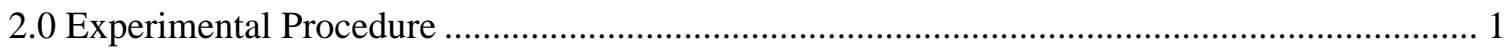

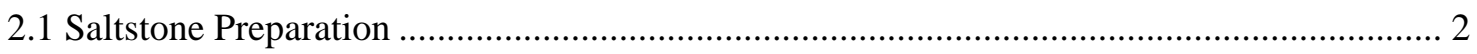

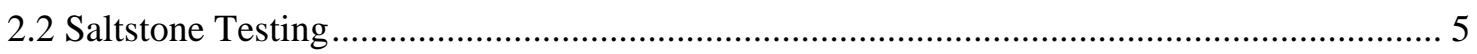

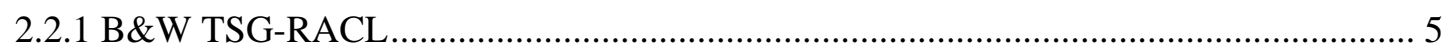

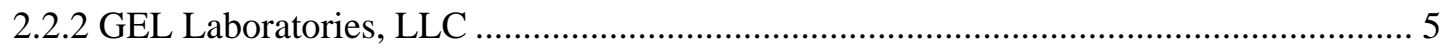

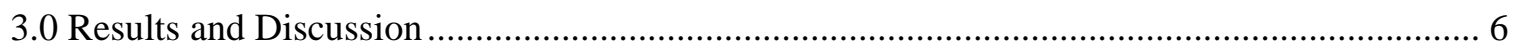

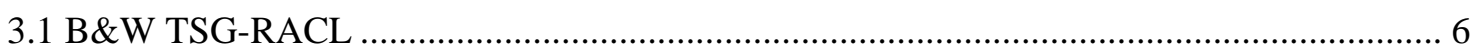

3.1.1 Comparison of Results to Regulatory Limits ................................................................. 7

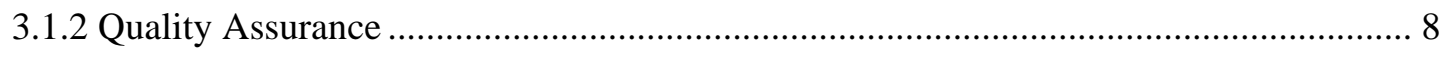

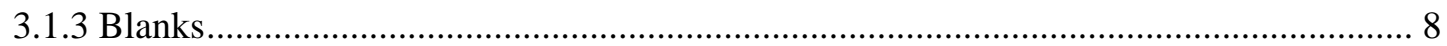

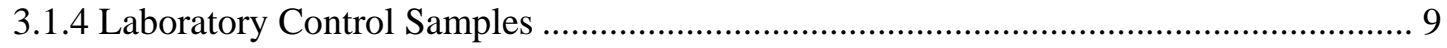

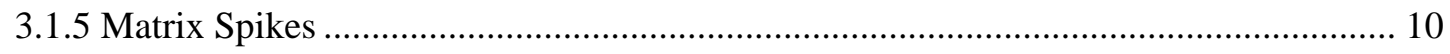

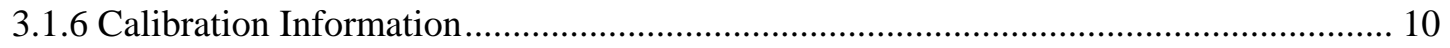

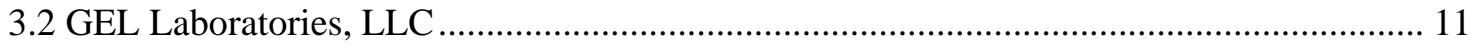

3.2.1 Comparison of Results to Regulatory Limits ............................................................... 11

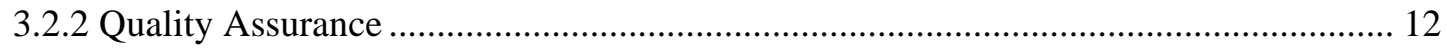

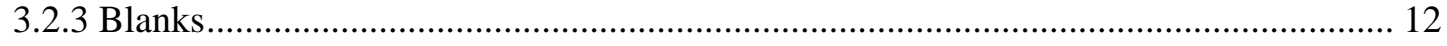

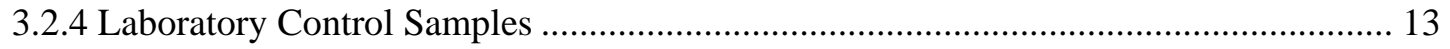

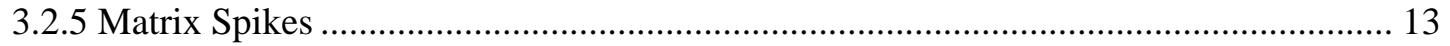

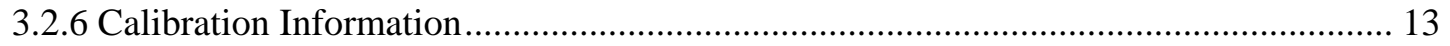

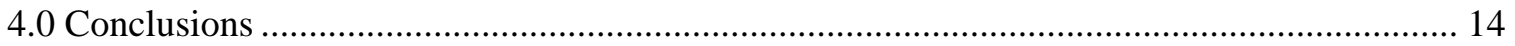

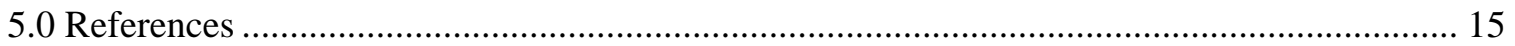




\section{LIST OF TABLES}

Table 2-1. Sample Results of TCLP Metals from Tank 50H WAC Analysis.............................. 3

Table 2-2. Customer Recommended Values for Preparation of TCLP Sample............................. 3

Table 3-1. TCLP Leachates RCRA Metal Concentrations, DLs, and QLs. ................................. 6

Table 3-2. Saltstone TCLP Results and Corresponding Regulatory Limits................................. 8

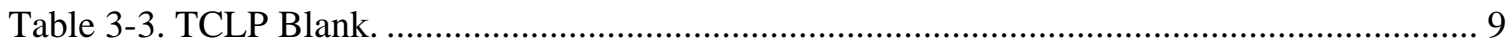

Table 3-4. RCRA Metal Laboratory Control Sample......................................................................... 9

Table 3-5. TCLP Leachates RCRA Metal Matrix Spike and Duplicate Results........................... 10

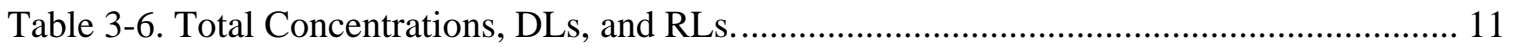

Table 3-7. Saltstone Total Results and Corresponding Regulatory Limits. ................................ 12

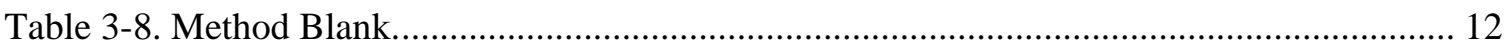

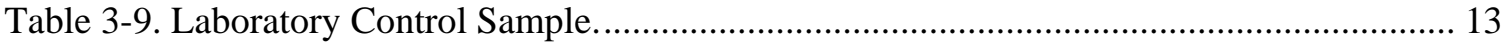

\section{LIST OF FIGURES}

Figure 2-1. Flowchart of Saltstone preparation and analysis. ................................................. 2

Figure 2-2. Data sheet for the Saltstone mix used to prepare the 3Q10 TCLP sample................. 4 


\section{LIST OF ABBREVIATIONS}

$\begin{array}{ll}\text { B\&W TSG- } & \text { B \& W Technical Services Group-Radioisotope and Analytical } \\ \text { RACL } & \text { Chemistry Laboratory } \\ \text { CVAA } & \text { Cold Vapor Atomic Absorption } \\ \text { DL } & \text { Detection Limit } \\ \text { DSS-HT } & \text { Decontaminated Salt Solution Hold Tank } \\ \text { ESS-WP } & \text { Environmental Services Section - Waste Programs } \\ \text { ETP } & \text { Effluent Treatment Project } \\ \text { ICP-MS } & \text { Inductively Coupled Plasma - Mass Spectrometer } \\ \text { ISWLF } & \text { Industrial Solid Waste Landfill } \\ \text { LCS } & \text { Laboratory Control Sample } \\ \text { MCL } & \text { Maximum Contaminant Level } \\ \text { MCU } & \text { Modular Caustic Side Solvent Extraction Unit } \\ \text { MS } & \text { Matrix Spike } \\ \text { MSD } & \text { Matrix Spike Duplicate } \\ \text { QL } & \text { Quantitation Limit } \\ \text { RCRA } & \text { Resource Conservation and Recovery Act } \\ \text { RL } & \text { Reporting Limit } \\ \text { RPD } & \text { Relative Percent Differences } \\ \text { SCDHEC } & \text { South Carolina Department of Health and Environmental Control } \\ \text { SCHWMR } & \text { South Carolina Hazardous Waste Management Regulations } \\ \text { SDF } & \text { Saltstone Disposal Facility } \\ \text { SDG } & \text { Sample Delivery Group } \\ \text { SPF } & \text { Saltstone Production Facility } \\ \text { SRNL } & \text { Savannah River National Laboratory } \\ \text { TCLP } & \text { Toxic Characteristic Leaching Procedure } \\ \text { UHC } & \text { Underlying Hazardous Constituent } \\ \text { UTS } & \text { Universal Treatment Standards } \\ & \end{array}$




\subsection{Introduction}

The Saltstone Production Facility (SPF) receives waste from Tank 50H for treatment. In the third quarter of the 2010 calendar year (3QCY10), Tank 50H accepted transfers of approximately 76 kgal from the Effluent Treatment Project (ETP), approximately 7 kgal from Tank 710 - the HCanyon General Purpose Evaporator, approximately 57 kgal from the H-Canyon Super Kukla campaign, approximately 58 kgal from the Modular Caustic Side Solvent Extraction Unit (MCU) Decontaminated Salt Solution Hold Tank (DSS-HT), and approximately 6 kgal from other sources.

The Saltstone Grout Sampling plan provides the South Carolina Department of Health and Environmental Control (SCDHEC) with the chemical and physical characterization strategy for the salt solution which is to be disposed of in the Z-Area Solid Waste Landfill (ISWLF) ${ }^{1}$. During operation, samples were collected from Tank $50 \mathrm{H}$ and grout samples prepared to determine the non-hazardous nature of the grout to meet the requirements of the South Carolina Hazardous Waste Management Regulations (SCHWMR) R.61-79.261.24(b) and R.61-79.268.48(a).

Savannah River National Laboratory (SRNL) was asked to prepare saltstone from samples of Tank 50H obtained July 1, 2010 during 3QCY10 to determine the non-hazardous nature of the grout. The samples were cured and shipped to Babcock \& Wilcox Technical Services GroupRadioisotope and Analytical Chemistry Laboratory (B\&W TSG-RACL) to perform the Toxic Characteristic Leaching Procedure (TCLP) ${ }^{2}$ and subsequent extract analysis on saltstone samples for the analytes required for the quarterly analysis saltstone sample. In addition to the eight toxic metals-arsenic, barium, cadmium, chromium, mercury, lead, selenium and silver-analytes included the underlying hazardous constituents (UHC) antimony, beryllium, nickel, and thallium which could not be eliminated from analysis by process knowledge. ${ }^{3}$ B\&W TSG-RACL provided subsamples to GEL Laboratories, LLC for analysis for the UHCs benzene, phenols and total and amenable cyanide.

\subsection{Experimental Procedure}

This section is a summary of the approach taken to prepare and characterize the saltstone samples. The saltstone sample preparation was performed at SRNL. Saltstone sample characterization was performed at both B\&W TSG-RACL facility in Lynchburg, Virginia and the GEL laboratory facility in Charleston, South Carolina. Figure 2-1 is a flowchart of the steps taken to prepare and characterize the saltstone samples. 


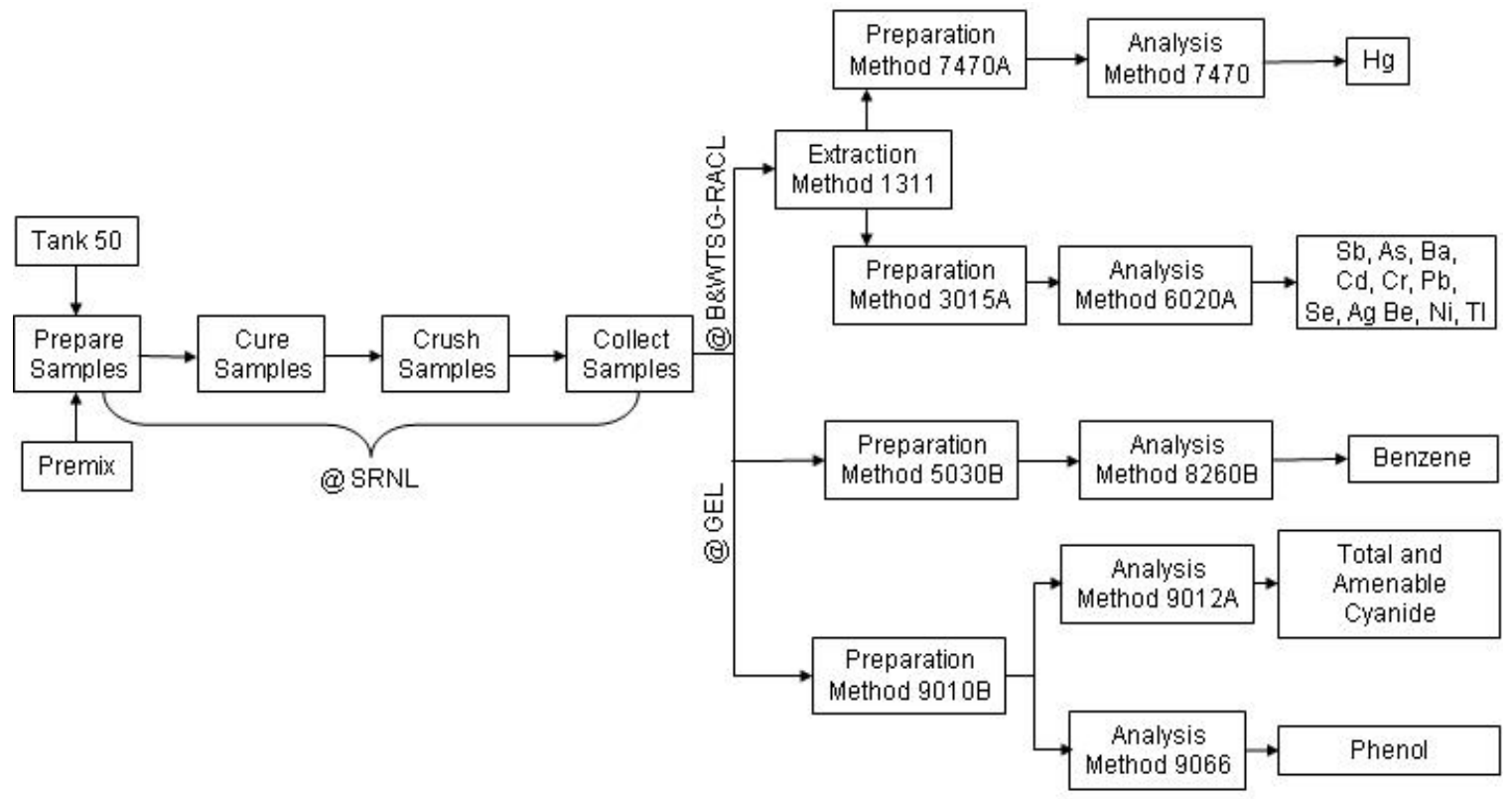

Figure 2-1. Flowchart of Saltstone preparation and analysis.

\subsection{Saltstone Preparation}

Saltstone preparation was performed at SRNL. The weight percent solids data used for the TCLP sample was taken from the quarterly Waste Acceptance Criteria (WAC) analyses performed on Tank $50 \mathrm{H}^{4}{ }^{4}$ Table 2-1 lists the concentration of TCLP metals of interest in the salt solution from the WAC analysis ${ }^{4}$ for the sample. As shown in Table 2-1, the contents of Tank $50 \mathrm{H}$ exceed the regulatory limits for antimony, chromium, mercury, phenol, and thallium and therefore must be treated and disposed of in a non-hazardous waste form. Table 2-2 contains the parameters used to prepare the TCLP sample. ${ }^{5}$

Saltstone samples for TCLP were prepared with the Tank $50 \mathrm{H}$ blended salt solution and a premix of cement, slag, and fly ash. Figure 2-2 shows the formulation used to prepare these samples. The salt solution, admixtures and premix materials were combined in a blender and mixed at low speed for one minute, inspected for incorporation of the premix, and then mixed at high speed for an additional two minutes. After the saltstone slurry was mixed, it was cast into a polyethylene zip top bag. The bag was laid flat and the air was expelled prior to sealing. The sample was cured flat in a polypropylene bag to facilitate the size reduction step needed to conform to the particle size requirements of the TCLP method.

After curing for not less than 28 days ${ }^{1}$ - 33 days for the 3 Q10 sample, the saltstone was removed from the container and a portion of the saltstone was crushed to particles less than 0.9 centimeters (3/8 inch) as prescribed by Section 7.13 of the TCLP method. ${ }^{2}$ The crushed saltstone was packaged into containers provided by Environmental Services Section - Waste Programs (ESSWP). After the saltstone has been crushed, sieved and packaged, the sample is deemed "collected." ESS-WP retrieved the samples from SRNL and transported them to B\&W TSGRACL for extraction and analysis. B\&W TSG-RACL repackaged a portion of the sample and shipped the sample to GEL Laboratories to perform totals analysis for the UHCs benzene, phenol and total and amenable cyanide.

\footnotetext{
${ }^{1}$ Samples are considered ready for analysis after 28 days. Samples are not crushed until shipment has been scheduled.
} 
Table 2-1. Sample Results of TCLP Metals from Tank 50H WAC Analysis.

\begin{tabular}{|c||c|c||}
\hline- & $\begin{array}{c}\text { Sample Results } \\
\text { (mg/L) }^{\mathbf{4}}\end{array}$ & $\begin{array}{c}\text { Regulatory Limits } \\
(\mathbf{m g} / \mathbf{L})\end{array}$ \\
\hline- & $\mathbf{3 Q 1 0}$ & Toxicity $^{\mathbf{a}}$ \\
\hline $\mathbf{A s}$ & $<0.114$ & 5 \\
\hline $\mathbf{B a}$ & $<0.978$ & 100 \\
\hline $\mathbf{C d}$ & $<0.696$ & 1 \\
\hline $\mathbf{C r}$ & 47.5 & 5 \\
\hline $\mathbf{P b}$ & $<0.433$ & 5 \\
\hline $\mathbf{H g}$ & 9.42 & 0.2 \\
\hline $\mathbf{S e}$ & $<0.228$ & 1 \\
\hline $\mathbf{A g}$ & $<1.77$ & 5 \\
\hline-- & -- & $\mathbf{U H C}$ \\
\hline Sb & $<5.70$ & 1.15 \\
\hline Be & $<0.058$ & 1.22 \\
\hline $\mathbf{N i}$ & 7.66 & 11 \\
\hline Tl & $<0.666$ & 0.20 \\
\hline- & - & $\mathbf{m g} / \mathbf{k g})$ \\
\hline benzene & $<0.150$ & 10 \\
\hline phenol & $<10.0$ & 6.2 \\
\hline cyanide (total) & $\mathrm{NM}$ & 590 \\
\hline cyanide (amenable) & $\mathrm{NM}$ & 30 \\
\hline \hline
\end{tabular}

NM - Not Measured

a SCHWMR R.61-79.261.24(b) "Characteristic of Toxicity."

b SCHWMR R.61-79.268.48 "Universal Treatment Standards.”

Table 2-2. Customer Recommended Values for Preparation of TCLP Sample.

\begin{tabular}{|c|c|}
\hline Parameter & $3 Q 10$ \\
\hline \hline Water-to-Premix ratio & 0.60 \\
\hline $\begin{array}{c}\text { (Daratard 17) gal/Ton premix } \\
\text { (Dow Corning Q2-1383A) } \\
\text { gal/Ton premix }\end{array}$ & 0.00 \\
\hline
\end{tabular}


Saltstone Mix Data Sheet

\begin{tabular}{|c|c|c|c|}
\hline \multicolumn{2}{|l|}{ MIX \# 0119} & \multicolumn{2}{|c|}{ Date: $\quad 8 / 16 / 2010$} \\
\hline Material & $\%$ & WT\% & Grams \\
\hline Waste Solution: Tank 50 7/1/10 3Q10 & & \multirow{3}{*}{44.19} & \multirow{3}{*}{217.81} \\
\hline Wt $\%$ Solids \# 24.10 & & & \\
\hline Grams Water 165.32 & & & \\
\hline Admixture: $\quad \underline{\text { Q2 Antifoam* }}$ & & 0.03 & 0.08 \\
\hline \multicolumn{4}{|l|}{ Admixture: } \\
\hline \multicolumn{4}{|l|}{ Admixture: } \\
\hline Premix & & 55.79 & 275.00 \\
\hline Cement ( $\%$ of Premix) & 10 & 5.58 & 27.50 \\
\hline Slag ( $\%$ of Premix) & 45 & 25.11 & 123.75 \\
\hline Fly Ash (\% of Premix) & 45 & 25.11 & 123.75 \\
\hline Total & 100 & 100.01 & 492.89 \\
\hline Water to Premix Ratio & \multicolumn{2}{|c|}{0.60} & \\
\hline \multicolumn{4}{|c|}{$\begin{array}{l}\text { Calculations: } \\
\text { Use CBO fly ash }\end{array}$} \\
\hline \multicolumn{4}{|l|}{ From customer: $0.60 \mathrm{w} / \mathrm{p}, 0.10 \mathrm{gpm}, 33 \mathrm{~T} / \mathrm{hr}$ dry feed } \\
\hline \multicolumn{4}{|c|}{ Q2 is diluted Q2 amount. In plant, diluted 1:4 in water. } \\
\hline \multicolumn{4}{|c|}{$\begin{array}{l}\text { *Actual amount of Q2 added to sample is } 0.078 \mathrm{~g} \text {. Q2 was diluted to a } 1: 4 \text { in water and } 100 \mathrm{uL} \\
\text { pipette was used to add the diluted Q2 to the sample. }\end{array}$} \\
\hline
\end{tabular}

Figure 2-2. Data sheet for the Saltstone mix used to prepare the $3 Q 10$ TCLP sample. ${ }^{5}$ 
SRNL-STI-2010-00679

Revision 0

\subsection{Saltstone Testing}

Saltstone testing was performed by B\&W TSG-RACL and GEL Laboratories, LLC. Activities associated with the 3QCY10 saltstone samples were:

\section{At B\&W TSG-RACL,}

- performing the TCLP extraction,

- digesting the TCLP leachate, and

- analyzing the digested leachate.

At GEL

- performing extractions on solid subsamples shipped from B\&W TSG-RACL and

- analyzing extracts.

\subsection{1 $B \& W T S G-R A C L$}

The samples arrived at B\&W TSG-RACL, Lynchburg, Virginia on September 23, 2010 for analysis. Shipping container temperatures were documented to be within specifications. The samples were delivered with proper chain of custody documentation and signatures. All sample containers arrived without any visible signs of tampering or breakage.

The Metals method 6020A analysis was performed on an X-7 Series Inductively Coupled Plasma - Mass Spectrometer (ICP-MS). The instrument measures ions produced by a radio-frequency inductively coupled plasma. Analyte species originating in a liquid are nebulized and the resulting aerosol transported by argon gas into the plasma torch. The ions produced by high temperatures are entrained in the plasma gas and introduced, by means of an interface, into a mass spectrometer. The ions produced in the plasma are sorted according to their mass-to-charge ratios and quantified with a channel electron multiplier. Mass interferences must be assessed and valid corrections applied or the data flagged to indicate problems.

The Metals method 7470A analysis was performed on a Leman PC 200 II instrument which consists of a cold vapor atomic absorption spectrometer (CVAA) set to detect mercury at a wavelength of $253.7 \mathrm{~nm}$. The mercury is reduced to the elemental state and aerated from solution in a closed system. The mercury vapor passes through a cell positioned in the light path of an atomic absorption spectrophotometer. Absorbance (peak height) is measured as a function of mercury concentration.

A portion of the leachate from the third quarter sample was used as the quality control sample (matrix spike) for the ICP-MS and CVAA.

\subsubsection{GEL Laboratories, LLC}

The subsamples arrived at GEL Laboratories, LLC, Charleston, South Carolina on September 30, 2010 for analysis. Shipping container temperatures were documented to be within specifications. All sample containers arrived without any visible signs of tampering or breakage. The sample arrived with the proper chain of custody documentation and signatures.

The method 8260B analysis was performed with an HP6890/HP5973 gas chromatograph/mass spectrometer using a J\&W DB-624 column. Methods 9012A and 9066 were performed using a Lachat QuickChem FIA+ 8000 Series. 


\subsection{Results and Discussion}

Results summarized in the following tables are from the data package for these analyses. ${ }^{7}$ Data is presented in these results as reported by the vendors.

\subsection{B\&W TSG-RACL}

Analytes detected but at concentrations too low to determine quantitatively have been flagged with the "B" qualifier. Analytes that were not detected have been flagged with the "U" qualifier. In addition to the results, Detection Limits (DLs) have been given. The DL is the minimum concentration of an analyte that can be identified, measured, and reported with $99 \%$ confidence that the concentration is above zero. The DL values given in the table are the results from this study adjusted for sample dilution. The Quantitation Limit (QL) is the lowest level at which an analyte may be accurately and reproducibly achieved.

Results in Table 3-1, when compared with the DLs and QLs, can be organized into three groups:

- $\quad$ Beryllium, silver and thallium were not detected in the leachate.

- Antimony, cadmium, chromium, lead, and nickel were detected below the QLs.

- Arsenic, barium, mercury, and selenium were detected in the leachates at concentrations above the QLs.

Table 3-1. TCLP Leachates RCRA Metal Concentrations, DLs, and QLs.

\begin{tabular}{|c|c|c|c|c|}
\hline- & Methods & $\begin{array}{l}\text { Sample } \\
\text { Limits } \\
(\mu \mathrm{g} / \mathrm{L})\end{array}$ & $\begin{array}{l}\text { Sample } \\
\text { Limits } \\
(\mu g / L)\end{array}$ & $\begin{array}{c}\text { Sample } \\
\text { Results } \\
(\mu g / L)\end{array}$ \\
\hline SRS ID & - & - & - & $3 Q 10$ \\
\hline B\&W ID & - & DL & QL & $\begin{array}{c}1009015 \\
01 \mathrm{~A}\end{array}$ \\
\hline Sb & $3015,6020 \mathrm{~A}$ & 0.133 & 11.111 & ${ }^{\mathrm{B}} 3.9$ \\
\hline As & $3015,6020 \mathrm{~A}$ & 0.100 & 5.556 & ${ }^{N_{2}} 24.3$ \\
\hline $\mathbf{B a}$ & $3015,6020 \mathrm{~A}$ & 0.439 & 55.556 & ${ }^{\mathrm{N}, \mathrm{E}} 186$ \\
\hline Cd & $3015,6020 \mathrm{~A}$ & 0.111 & 5.556 & ${ }^{\mathrm{B}} 0.61$ \\
\hline $\mathrm{Cr}$ & $3015,6020 \mathrm{~A}$ & 0.306 & 11.111 & ${ }^{\mathrm{B}} 4.3$ \\
\hline $\mathbf{P b}$ & $3015,6020 \mathrm{~A}$ & 0.483 & 5.556 & ${ }^{\mathrm{B}, \mathrm{N}_{3}} .5$ \\
\hline Hg & $7470 \mathrm{~A}$ & 0.07 & 0.200 & 0.40 \\
\hline Se & $3015,6020 \mathrm{~A}$ & 0.244 & 27.778 & 54.3 \\
\hline Ag & $3015,6020 \mathrm{~A}$ & 0.061 & 5.556 & ${ }^{\mathrm{U}} 0.06$ \\
\hline Be & $3015,6020 \mathrm{~A}$ & 0.156 & 5.556 & ${ }^{\mathrm{U}} 0.16$ \\
\hline $\mathbf{N i}$ & $3015,6020 \mathrm{~A}$ & 1.578 & 5.556 & ${ }^{\mathrm{B}} 2.7$ \\
\hline $\mathrm{Tl}$ & $3015,6020 \mathrm{~A}$ & 0.206 & 5.556 & $\overline{\mathrm{U}, \mathrm{N}} 0.21$ \\
\hline
\end{tabular}

- Indicates a location in the table for which an entry would not be appropriate.

${ }^{\mathrm{U}}$ Final concentration of the analyte was found to be below the DL.

${ }^{B}$ Analyte is present at a concentration above the DL but less than the QL

${ }^{\mathrm{N}}$ Associated Matrix Spike is outside percent recovery quality control criteria.

${ }^{\mathrm{E}}$ Associated Serial Dilution is outside percent difference quality control criteria. 


\subsubsection{Comparison of Results to Regulatory Limits}

Results from the TCLP leachate analyses from Table 3-1 are replicated in Table 3-2 — with units changed from $\mu \mathrm{g} / \mathrm{L}$ to $\mathrm{mg} / \mathrm{L}$-along with the regulatory limits that may be applied to the Saltstone waste form. Table 3-2 includes the SCHWMR R.61-79.261.24(b) limits above which a waste is to be considered characteristically hazardous for toxicity and the SCHWMR R.6179.268.48 Universal Treatment Standards (UTS) for hazardous constituents. In addition, Maximum Contaminant Levels (MCL's) from the State Primary Drinking Water Regulations ${ }^{2}$ also have been included in Table 3-2. By comparing the sample results and the regulatory limits in, the following conclusions can be made:

- The saltstone waste form was not characteristically hazardous for toxicity.

- The leachate metals concentrations were below the Nonwastewater Standard for all of the metals.

- Antimony, barium, beryllium, cadmium, chromium, lead, mercury, silver and thallium were below the MCL's.

- Arsenic and selenium exceeded the MCL.

- Nickel does not have a MCL.

The MCL is the limit for a constituent in drinking water. The MCL is used to determine the class of landfill required. At 10x MCL, a Class 3 landfill is required. The SDF vaults are permitted as a Class 3 landfill. None of the analyses were greater than 10x the MCL.

\footnotetext{
${ }^{2}$ Regulations 61-58 through 61-58.15 are promulgated pursuant to S.C. Code Sections 44-55-10 et seq. and are collectively known as the State Primary Drinking Water Regulations.
} 
SRNL-STI-2010-00679

Revision 0

Table 3-2. Saltstone TCLP Results and Corresponding Regulatory Limits.

\begin{tabular}{|c|c|c|c|c|}
\hline - & Sample Results (mg/L) & \multicolumn{3}{|c|}{ Regulatory Limits } \\
\hline SRS ID & \begin{tabular}{|c|}
$3 Q 10$ \\
\end{tabular} & Toxicity $^{\mathrm{a}}$ & UTS $^{\mathbf{b}}$ & $\mathrm{MCL}^{\mathrm{c}}$ \\
\hline B\&W ID & 1009015-01A & $(\mathrm{mg} / \mathrm{L})$ & $\begin{array}{c}\text { Nonwastewater } \\
\text { Standard } \\
\text { (mg/L TCLP) }\end{array}$ & $(\mathrm{mg} / \mathrm{L})$ \\
\hline Sb & B3.90E-03 & - & 1.15 & 0.006 \\
\hline As & $\mathrm{N}_{2.43 \mathrm{E}-02}$ & 5 & 5 & 0.010 \\
\hline $\mathbf{B a}$ & $\mathrm{N}, \mathrm{E} 1.86 \mathrm{E}-01$ & 100 & 21 & 2 \\
\hline Cd & ${ }^{\mathrm{B}} 6.10 \mathrm{E}-04$ & 1 & 0.11 & 0.005 \\
\hline $\mathrm{Cr}$ & ${ }^{\mathrm{B}} 4.30 \mathrm{E}-03$ & 5 & 0.6 & 0.1 \\
\hline $\mathbf{P b}$ & ${ }^{\mathrm{B}, \mathrm{N}} 3.50 \mathrm{E}-03$ & 5 & 0.75 & $0.015^{\mathrm{d}}$ \\
\hline Hg & 4.00E-04 & 0.2 & 0.025 & 2E-03 \\
\hline Se & 5.43E-02 & 1 & 5.7 & 0.05 \\
\hline Ag & U6.00E-05 & 5 & 0.14 & $0.1^{\mathrm{e}}$ \\
\hline Be & $\mathrm{U}_{1.60 \mathrm{E}-04}$ & - & 1.22 & 4E-03 \\
\hline $\mathbf{N i}$ & ${ }^{\mathrm{B}} 2.70 \mathrm{E}-03$ & - & 11 & - \\
\hline Tl & $\mathrm{U}, \mathrm{N} 2.10 \mathrm{E}-04$ & - & 0.20 & 2E-03 \\
\hline
\end{tabular}

- Indicates a location in the table for which an entry would not be appropriate.

${ }^{\mathrm{U}}$ Final concentration of the analyte was found to be below the DL.

${ }^{B}$ Analyte is present at a concentration above the DL but less than the QL.

${ }^{\mathrm{N}}$ Associated Matrix Spike is outside percent recovery quality control criteria.

${ }^{\mathrm{E}}$ Associated Serial Dilution is outside percent difference quality control criteria.

a R.61-79.261.24(b) "Characteristic of Toxicity."

${ }^{\mathrm{b}}$ R.61-79.268.48 "Universal Treatment Standards."

"SCDHEC State Primary Drinking Water Regulation Maximum Contaminant Levels.

${ }^{\mathrm{d}}$ Lead action level from SCDHEC 61-58.11.B.

${ }^{\mathrm{e}}$ Secondary drinking water parameter.

\subsubsection{Quality Assurance}

The following subsections include summaries of results from blanks, laboratory control samples, matrix spikes, and matrix spike duplicates. The data package also includes data for calibration verifications, interference checks, and serial dilutions. ${ }^{7}$

\subsubsection{Blanks}

Blank concentrations are given in Table 3-3. In the TCLP Blank, selenium was present at a detectable concentration. Arsenic, barium, cadmium, chromium, lead, and nickel were present at levels above their respective DLs, but below their respective QLs. Antimony, beryllium, silver and thallium were found to be below the DLs. 
SRNL-STI-2010-00679

Revision 0

Table 3-3. TCLP Blank.

\begin{tabular}{|c||c|}
\hline Analyte & TCLP Blank $(\mu \mathrm{g} / \mathrm{L})$ \\
\hline \hline Sb & ${ }^{\mathrm{U}} 0.13$ \\
\hline As & ${ }^{\mathrm{B}, \mathrm{N}} 1.7$ \\
\hline Ba & ${ }^{\mathrm{B}, \mathrm{N}, \mathrm{E}} 6.8$ \\
\hline $\mathbf{C d}$ & ${ }^{\mathrm{B}} 0.72$ \\
\hline $\mathbf{C r}$ & ${ }^{\mathrm{B}} 2.3$ \\
\hline $\mathbf{P b}$ & ${ }^{\mathrm{B}, \mathrm{N}} 4.4$ \\
\hline $\mathbf{H g}$ & ${ }^{\mathrm{U}} 0.07$ \\
\hline Se & 34.7 \\
\hline $\mathbf{A g}$ & ${ }^{\mathrm{U}} 0.06$ \\
\hline $\mathbf{B e}$ & ${ }^{\mathrm{U}} 0.16$ \\
\hline $\mathbf{N i}$ & ${ }^{\mathrm{B}} 5.2$ \\
\hline $\mathbf{T l}$ & ${ }^{\mathrm{U}, \mathrm{N}} 0.21$ \\
\hline
\end{tabular}

${ }^{\mathrm{B}}$ Analyte is present at a concentration above the DL but less than the QL.

${ }^{\mathrm{U}}$ Final concentration of the analyte was found to be below the DL.

${ }^{\mathrm{N}}$ Associated Matrix Spike is outside percent recovery quality control criteria.

${ }^{\mathrm{E}}$ Associated Serial Dilution is outside percent difference quality control criteria.

\subsubsection{Laboratory Control Samples}

Results from the Laboratory Control Sample (LCS) are given in Table 3-4. The LCS post spike recoveries met USEPA SW-846 acceptance limits for all elements. Laboratory Control Samples are clean aqueous solutions analyzed to assure integrity of the analytical technique exclusive of matrix effects.

Table 3-4. RCRA Metal Laboratory Control Sample

\begin{tabular}{||c||c|c||c||}
\hline \hline \multicolumn{1}{|c||}{ Analyte } & Laboratory Control $(\boldsymbol{\mu g} / \mathbf{L})$ & Recovery (\%) \\
\hline- & True & Measured & $(80-120)$ \\
\hline \hline Sb & 328.0 & 330 & 101 \\
\hline $\mathbf{A s}$ & 719.0 & 714 & 99 \\
\hline $\mathbf{B a}$ & 463.0 & 486 & 105 \\
\hline $\mathbf{C d}$ & 476.0 & 466 & 98 \\
\hline $\mathbf{C r}$ & 162.0 & 169 & 104 \\
\hline $\mathbf{P b}$ & 280.0 & 295 & 105 \\
\hline $\mathbf{H g}$ & 10.8 & 9.98 & 92.4 \\
\hline $\mathbf{S e}$ & 1000.0 & 963 & 96 \\
\hline $\mathbf{A g}$ & 194.0 & 198 & 102 \\
\hline $\mathbf{B e}$ & 136.0 & 124 & 91 \\
\hline $\mathbf{N i}$ & 533.0 & 491 & 92 \\
\hline $\mathbf{T l}$ & 142.0 & 138 & 97 \\
\hline
\end{tabular}




\subsubsection{Matrix Spikes}

Results from analysis of the matrix spike (MS) and matrix spike duplicates (MSD) are given in Table 3-5. The initial concentrations in the second column are reproduced from Table 3-1. These results show that:

- The percent recoveries (\%R) obtained from the MS analyses met the recommended quality control acceptance criteria for percent recoveries (75 - 125\%) for all applicable analytes.

- The percent recoveries (\%R) obtained from the MSD analyses met the recommended quality control acceptance criteria for percent recoveries $(75-125 \%)$ for all applicable analytes with the exception of $\mathrm{As}, \mathrm{Ba}, \mathrm{Pb}$, and $\mathrm{Tl}$.

- The RPD(s) between the MS and MSD met the acceptance limits $(0-20 \%)$.

Table 3-5. TCLP Leachates RCRA Metal Matrix Spike and Duplicate Results.

\begin{tabular}{|c|c|c|c|c|c|c|c||}
\hline Analyte & \multicolumn{2}{|c|}{$\begin{array}{c}\text { Initial Concentrations } \\
(\mu \mathbf{g} / \mathbf{L})\end{array}$} & \multicolumn{2}{|c|}{$\begin{array}{c}\text { Spiked Sample } \\
(\mu \mathbf{g} / \mathbf{L})\end{array}$} & \multicolumn{2}{|c|}{ Recovery (\%) } & $\begin{array}{c}\text { RPD } \\
(\%)\end{array}$ \\
\hline- & $\begin{array}{c}\text { B\&W ID } \\
\mathbf{1 0 0 9 0 1 5}- \\
\mathbf{0 1 A}\end{array}$ & $\begin{array}{c}\text { Spike } \\
\text { Added }\end{array}$ & Spike & $\begin{array}{c}\text { Spike } \\
\text { Duplicate }\end{array}$ & Spike & $\begin{array}{c}\text { Spike } \\
\text { Duplicate }\end{array}$ & - \\
\hline $\mathbf{S b}$ & ${ }^{\mathrm{B}} 3.9$ & 1000 & 1055 & 1171 & 105 & 117 & 10 \\
\hline $\mathbf{A s}$ & ${ }^{\mathrm{N}} 24.3$ & 500 & 575 & 687 & 110 & 132 & 18 \\
\hline $\mathbf{B a}$ & ${ }^{\mathrm{N}, \mathrm{E}} 186$ & 2500 & 3006 & 3367 & 113 & 127 & 11 \\
\hline $\mathbf{C d}$ & ${ }^{\mathrm{B}} 0.61$ & 250 & 244 & 271 & 98 & 108 & 10 \\
\hline $\mathbf{C r}$ & ${ }^{\mathrm{B}} 4.3$ & 1000 & 1034 & 1150 & 103 & 115 & 11 \\
\hline $\mathbf{P b}$ & ${ }^{\mathrm{B}, \mathrm{N}} 3.5$ & 500 & 591 & 660 & 117 & 131 & 11 \\
\hline $\mathbf{H g}$ & 0.40 & 5.00 & 5.39 & 5.77 & 99.8 & 107.4 & 6.8 \\
\hline $\mathbf{S e}$ & 54.3 & 250 & 308 & 359 & 102 & 122 & 15 \\
\hline $\mathbf{A g}$ & ${ }^{\mathrm{U}} 0.06$ & 250 & 240 & 266 & 96 & 107 & 10 \\
\hline $\mathbf{B e}$ & ${ }^{\mathrm{U}} 0.16$ & 250 & 237 & 258 & 95 & 103 & 8 \\
\hline $\mathbf{N i}$ & ${ }^{\mathrm{B}} 2.7$ & 1000 & 876 & 974 & 87 & 97 & 11 \\
\hline $\mathbf{T l}$ & ${ }_{\mathrm{U}, \mathrm{N}} 0.21$ & 250 & 291 & 327 & 117 & 131 & 12 \\
\hline \hline
\end{tabular}

${ }^{\mathrm{U}}$ Final concentration of the analyte was found to be below the DL.

${ }^{\mathrm{B}}$ Analyte is present at a concentration above the DL but less than the QL.

${ }^{\mathrm{N}}$ Associated Matrix Spike is outside percent recovery quality control criteria.

${ }^{\mathrm{E}}$ Associated Serial Dilution is outside percent difference quality control criteria.

\subsubsection{Calibration Information}

- All initial calibration requirements have been met for this sample delivery group (SDG).

- All Contract Required Reporting Limit standard(s) met the referenced advisory control limits with the exception of NI.

- All interference check samples associated with this SDG met the established acceptance criteria.

- All continuing calibration blanks bracketing this batch met the established acceptance criteria.

- All continuing calibration verifications bracketing this SDG met the acceptance criteria. 


\subsection{GEL Laboratories, LLC}

GEL reports general chemistry analyses on the organics in the sample. If the concentrations of benzene, phenol and cyanide are not detected or below the detection limit $(<\mathrm{MDL})$ the result is reported as "ND". Analytes detected but at concentrations too low to determine quantitatively have been flagged with the "J" qualifier. Analytes that were not detected have been flagged with the "U" qualifier. In addition to the results, Detection Limits (DLs) and Reporting Limits (RLs) have been given. The DL is the minimum concentration of an analyte that can be identified, measured, and reported with 99\% confidence that the concentration is above zero. The DL values given in Table 3-6 are the results from this study adjusted for sample dilution. The RL is the lowest level at which an analyte may be accurately and reproducibly quantitated.

Table 3-6. Total Concentrations, DLs, and RLs.

\begin{tabular}{||c||c|c|c||c||}
\hline- & Methods & $\begin{array}{c}\text { Sample } \\
\text { Limits } \\
(\mu \mathrm{g} / \mathrm{kg})\end{array}$ & $\begin{array}{c}\text { Sample } \\
\text { Limits } \\
(\mu \mathrm{g} / \mathrm{kg})\end{array}$ & $\begin{array}{c}\text { Sample } \\
\text { Results } \\
(\mu \mathrm{g} / \mathrm{kg})\end{array}$ \\
\hline SRS ID & - & - & - & $\mathbf{3 Q 1 0}$ \\
\hline GEL ID & - & $\mathbf{D L}$ & $\mathbf{R L}$ & $\mathbf{2 6 1 8 1 1 0 0 1}$ \\
\hline \hline benzene & $5030,8260 \mathrm{~B}$ & 42.6 & 142 & $\mathrm{ND}$ \\
\hline phenol & $9010 \mathrm{~B}, 9066$ & 94.7 & 296 & 603 \\
\hline $\begin{array}{c}\text { cyanide } \\
\text { (total) }\end{array}$ & $9010 \mathrm{~B}, 9012 \mathrm{~A}$ & 111 & 347 & 12100 \\
\hline $\begin{array}{c}\text { cyanide } \\
\text { (amenable) }\end{array}$ & $9012 \mathrm{~A}$ & 111 & 347 & 11900 \\
\hline
\end{tabular}

- Indicates a location in the table for which an entry would not be appropriate.

${ }^{\mathrm{U}}$ Final concentration of the analyte was found to be below the DL.

\subsubsection{Comparison of Results to Regulatory Limits}

Results from the analyses from Table 3-6 are replicated in Table 3-7 — with units changed from $\mu \mathrm{g} / \mathrm{kg}$ to $\mathrm{mg} / \mathrm{kg}$ - along with the regulatory limits that may be applied to the Saltstone waste form. Table 3-7 includes the SCHWMR R.61-79.268.48 Universal Treatment Standards (UTS) for hazardous constituents. By comparing the sample results and the regulatory limits in Table 3-7, it can be concluded that for all of the analytes, the concentrations were below the Nonwastewater Standard. 
Table 3-7. Saltstone Total Results and Corresponding Regulatory Limits.

\begin{tabular}{|c|c|c|}
\hline \multicolumn{1}{|c|}{} & $\begin{array}{c}\text { Sample } \\
\text { Results } \\
(\mathbf{m g} / \mathbf{k g})\end{array}$ & $\begin{array}{c}\text { Regulatory Limits } \\
(\mathbf{m g} / \mathbf{k g})\end{array}$ \\
\hline SRS ID & $\mathbf{3 Q 1 0}$ & \multirow{2}{*}{ UTS $^{\mathbf{b}}$} \\
\hline GEL ID & $\mathbf{2 6 1 8 1 1 0 0 1}$ & \\
\hline benzene & ${ }^{\mathrm{N}} \mathrm{ND}$ & 10 \\
\hline phenol & 0.603 & 6.2 \\
\hline cyanide (total) & 12.1 & 590 \\
\hline cyanide (amenable) & 11.9 & 30 \\
\hline
\end{tabular}

- Indicates a location in the table for which an entry would not be appropriate.

${ }^{\mathrm{U}}$ Final concentration of the analyte was found to be below the DL.

${ }^{\mathrm{b}}$ R.61-79.268.48 “Universal Treatment Standards”.

\subsubsection{Quality Assurance}

The following subsections include summaries of results from blanks, laboratory control samples, matrix spikes, and matrix spike duplicates. The data package for this task also includes data for calibration verifications, interference checks, and serial dilutions.

\subsubsection{Blanks}

Blank concentrations are given in Table 3-8. Target and non target analytes were detected in the Method Blank below the reporting limit. Amenable to chlorination cyanide is determined by subtracting the results determined in the chlorinated cyanide test from those determined in the total cyanide test. The Method Blanks analyzed with this Sample Delivery Group (SDG) met the acceptance criteria.

Table 3-8. Method Blank.

\begin{tabular}{||c||c||}
\hline Analyte & $\begin{array}{c}\text { Method Blank } \\
(\mu \mathrm{g} / \mathrm{kg})\end{array}$ \\
\hline \hline benzene & ${ }^{\mathrm{U}} \mathrm{ND}$ \\
\hline phenol & ${ }^{\mathrm{U}} \mathrm{ND}$ \\
\hline cyanide (total) & ${ }^{\mathrm{U}} \mathrm{ND}$ \\
\hline cyanide (amenable) & -- \\
\hline
\end{tabular}

- Indicates a location in the table for which an entry would not be appropriate.

${ }^{\mathrm{U}}$ Final concentration of the analyte was found to be below the DL.

ND - Not Detectable 


\subsubsection{Laboratory Control Samples}

Results from the Laboratory Control Sample (LCS) are given in Table 3-9. All LCS recoveries met the vendor laboratory acceptance. Laboratory Control Samples are clean aqueous solutions analyzed to assure integrity of the analytical technique exclusive of matrix effects.

Table 3-9. Laboratory Control Sample.

\begin{tabular}{|c|c|c|c|c|c|}
\hline Analyte & \multicolumn{3}{|c|}{$\begin{array}{c}\text { Laboratory Control } \\
(\mu \mathrm{g} / \mathrm{kg})\end{array}$} & \multirow{2}{*}{\multicolumn{2}{|c|}{$\begin{array}{c}\text { Recovery (\%) } \\
-\end{array}$}} \\
\hline- & True & Mea & ured & & \\
\hline benzene & 50.0 & \multicolumn{2}{|c|}{49.6} & \multicolumn{2}{|c|}{99.1} \\
\hline phenol & 2090 & 1980 & 2260 & 95.2 & 109 \\
\hline cyanide (total) & 67900 & 54000 & 53800 & 79.5 & 79.2 \\
\hline cyanide (amenable) & -- & \multicolumn{2}{|c|}{-- } & \\
\hline
\end{tabular}

\subsubsection{Matrix Spikes}

Total cyanide is the only method where a matrix spike would be applicable; however, no samples were analyzed because of the highly radioactive sample matrix.

\subsubsection{Calibration Information}

- All initial calibration requirements have been met for this sample delivery group (SDG).

- All Contract Required Detection Limit standard(s) met the referenced advisory control limits.

- All interference check samples associated with this SDG met the established acceptance criteria.

- All continuing calibration blanks bracketing this batch met the established acceptance criteria.

- All continuing calibration verifications bracketing this SDG met the acceptance criteria. 


\subsection{Conclusions}

Preparation of the 3QCY10 saltstone samples and the subsequent TCLP analyses showed that:

- The saltstone waste form disposed of in the Saltstone Disposal Facility in 3QCY10 was not characteristically hazardous for toxicity.

- The concentrations of the eight RCRA metals and UHCs identified as possible in the saltstone waste form were present at levels below the UTS.

- Analyses met all quality assurance specifications of USEPA SW-846.

The saltstone waste form placed in the Saltstone Disposal Facility in 3QCY10 met the SCHWMR R.61-79.261.24(b) RCRA metals requirements for a nonhazardous waste form. The TCLP leachate concentrations were less than 5x the MCLs in SCDHEC Regulations R.61-107.19, Part I C.

The saltstone waste form placed in the Saltstone Disposal Facility in 3QCY10 met the R.6179.268.48(a) non wastewater treatment standards.

Analyses met all USEPA SW-846 quality assurance requirements with the exception of the laboratory control sample recoveries from GEL Laboratories. All other limits on holding times, laboratory control sample recoveries, matrix spike recoveries, serial dilution results when applicable, calibration verification, and interference checks were within the quality assurance requirements.. 


\subsection{References}

1. Liner, K.R., "Saltstone Grout Sampling (U)," Savannah River Site, ESH-EPG-200400318, 2004.

2. Toxicity Characteristic Leaching Procedure," EPA SW-846, Procedure 1311.

3. Britt, T.E., "Assessment of Regulated Organics Under 40 CFR Part 268, Section 49, Universal Treatment Standards, Relative to SRS Tank Farm Waste," Savannah River Site, LWO-LWE-2007-00052, 2007.

4. Reigel, M.M. and Bibler, N.E., "Tables Containing Results for the Third Quarter 2010 Tank 50 WAC Sample: Chemical and Radionuclide Contaminant Results," Savannah River National Laboratory, Aiken, SC, SRNL-L3100-2010-00179 Rev. 0, September 20, 2010.

5. $\quad$ Reigel, M.M., "Saltstone TCLP," Savannah River National Laboratory, SRNL-NB-200900076.

6. $\quad$ Liner, K.R., Nov. 28, 2007, Private Communication

7. Reigel, M.M., "Data Package From Vendor for 3QCY10 TCLP Analysis," Savannah River National Laboratory, Aiken, SC, SRNL-L3100-2010-00222, November 1, 2010. 